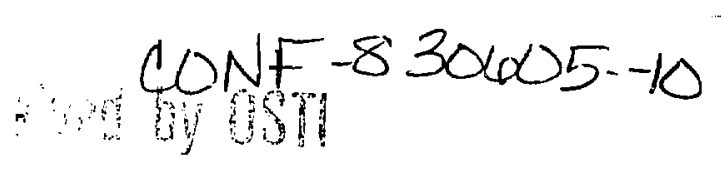

A.RR 221988
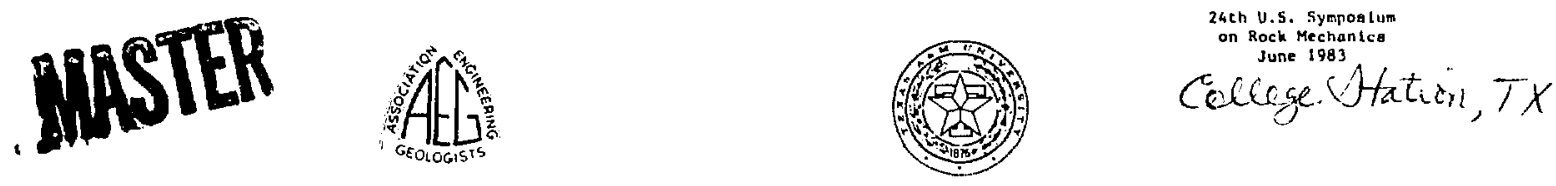

\title{
FIRST PHASE OF SMALL DIAMETER HEATER EXPERIMENTS IN TUFF
}

\author{
CONF-830605--10 \\ DE 86009490
}

\author{
ROGER M. ZIMMERMAN \\ NNWSI Geotechnical Projects Division \\ Sandia National Laboratories \\ Albuquerque, NM 87185
}

\begin{abstract}
As part of the Nevada Nuclear Waste Storage Investigations (NNWSI) project, we have undertaken small diameter heater experiments in the G-Tunnel Undergrownd Facility on the Nevada Test Site (NTS). These experiments are to evaluate the thermal and hydrothermal behavior which might be encountered if heat producing nuclear waste wire disposed of in welded and nonulelded tuffs. The two Phase I experiments discussed have focused on vertical borehole emplacements.

In each experiment, temperatures were measured along the surface of the 10.: $\mathrm{cm}$ diameter heater and the $12.7 \mathrm{~cm}$ diameter boreholes. For each experiment, measurements were compared with computer model representations. Maximum temperatures reached were: $196^{\circ} \mathrm{C}$ for the welded tuff after 21 days of operations at $800 \mathrm{~W}$ and $173^{\circ} \mathrm{C}$ for the nonwelded tuff after 35 days of operations at 500w. Computed results indicate that the same heat transfer model (includes conduction and radiation on $(y)$ can describe the behavior of both tuffs using empimical techniques to describe pore water vaporization.

Hydrothermal measurements revealed heat-induced water migration. Results indicated that small amounts of liquid water migrated into the welded tuff borehole early in the heating period. Once the rock-wall temperatures exceeded $94^{\circ} \mathrm{C}$, in both tuffs, there was mass transport of water vapor as evidence indicated condensation cooler regions. Borehole pressures remained essentially ambient during the thermal periods.
\end{abstract}

\section{INTRODUCTION}

Volcanic tuffs on and adjacent to the Nevada Test Site (NTS) are being considered by the Department of Energy (DOE) for the possible geologic disposal of commercial high level radioactive wastes. The Nevada Nuclear Waste Storage Invest1gations (NNWSI) project was established by DOE in 1977 to evaluate such disposal. Sandia National Laboratories, one of the participants in the NNWSI project, has as one of its responsibilities the development of the rock mechanics program to support the design of a repository in tuff. This program includes evaluations of the thermal, mechanical, and hydrothermal (heat-induced water migration) effects on the surrounding rock resulting from excavating the repository and emplacing the nuclear waste.

The rock mechanics field program has begun in the G-Tunnel Underground Facility; later experiments are to be incorporated into investigations in Yucca Mountain, the potential candidate repository site, when access can be provided. This paper reports on the results of the first 
two field experiments in the rock mechanics program, the Phase I small diameter heater experiments. These small diameter heater experiments are scheduled for G-tunnel, in two phases (Zimmerman 1982). Phase I experiments are intended to reveal the pertinent thermal (heat transfer) and hydrothermal behavior of welded tuffs (porosity< $25 \%$, relatively unjointed, ductile rock) and nonwelded tuffs (porosity > $25 \%$, relatively unjointed ductile rock). Both types of tuff are present in Yucca Mountain and determination of phenomena important to waste disposal are needed. At least one Phase II experiment is planned to evaluate emplacement concepts in welded tuff. All experiments art designed to define the thermal and hydrothermal behavior so findings can be incorpor ted into the design of more elaborate canister-scale experiments which emphasize thermomechanical responses. Results from these two phases of small diameter heater experiments also support NNWSI repository design efforts by providing preliminary field evaluations of heat transfer models. Thermal and hydrothermal data also aid in definition of the waste package environment.

\section{SCOPE}

Experiments were designed to evaluate the phenomena that occurred in a vertical wasce emplacement borehole in a simulated nuclear waste repositcry-like setting. Temperature measurements were made along the length of the heater and borehole wall - to evaluate the effects on heat transfer resulting from dewatering the partially initially saturated ( 80 to $95 \%$ ) tuffs. Hydruthermal measurements included determining the borehole pressure and the quantities of water in the bottom of the borehole as well as observing where vapor had condensed in the total system.

This paper summarizes the results for the Phise I experiments and evaluates the adequacy of available empiricaI heat transier models. The emphasis is on the measurement results and evaluations rather than on instrumentation and hardware functioning, although components are described for completeriess.

\section{EXPERIMENTAL SETUP}

Components

The experimental setup is shown in Figure 1. At the lower end is the stainless steel heater unit (HU), a self- contained unit made up of the heated section $(1.2 \mathrm{~m})$, insulated section (next $0.6 \mathrm{~m}$ ), terminal section (for electrical connections), and the handling pipe. The heater unit is $10.2 \mathrm{~cm}$ in diameter., 'Immediately above the heater are alunfnum. noneycomb segments, $11.4 \mathrm{~cm}$ in dianeter, used as a space filler to minimize convection.

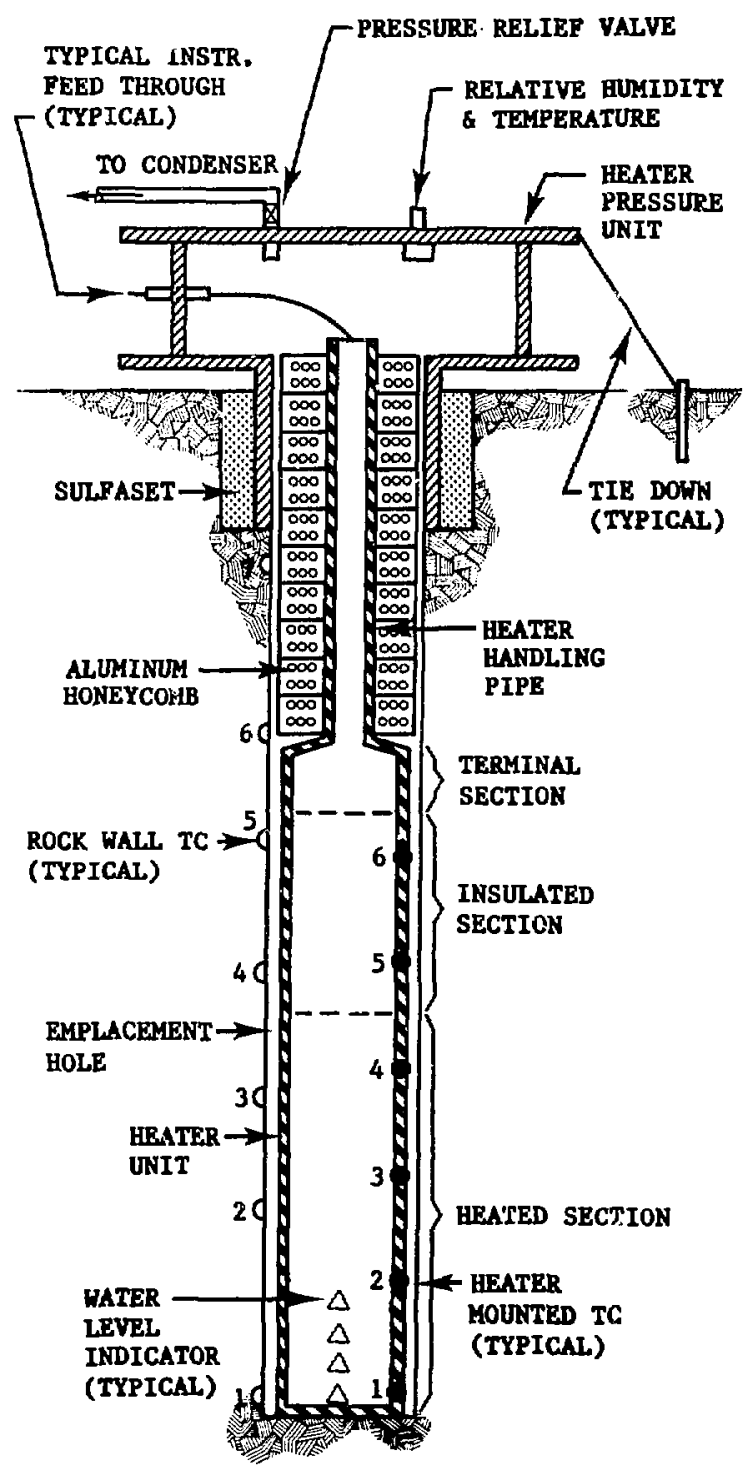

Figure 1. Smal1 Diameter Heater Section 
At the top is the heater pressure unit (HPU). This aluminum unit is attached to a collar, which is bonded to the emplacement hole with sulfaset. The heater pressure unit contains feed-throughs for all borehole instrumentation so that a pressure seal can be maintained within the borehole.

Emplacement holes were slightly different for each of the experiments, but the dianeters were a constant $12.7 \mathrm{~cm}$. The hole in welded tuff was in a fractured, orittle material. A design requirement was that the bottom $0.3 \mathrm{~m}$ be in intact rock to minimize water loss through fractures. It was necessary to drill the hole $3.2 \mathrm{~m}$ deep to achieve this. The welded tuff hole was significantly fractured above this level.. The hole in nonwelded tuff was $2.4 \mathrm{~m}$ deep. This hole was unfractured over the heated length.

\section{Measurements}

The heater unit contained three different measurement systems. Six thermocouples were located on each of three 1 ines spaced at $120^{\circ}$ around the periphery for the heater surface measurements. Vertical locations are provided in Table 1. Five thermocouples were placed inside the heater as part of the second system. The third measurement systam consisted of surface water level sensors, placed along the lower $38 \mathrm{~cm}$ of the heater to measure water level accumulations in $2.5 \mathrm{~cm}$ increments.

The heater pressure unit contained a resistance temperature device (RTD), a digital humidity analyzer, and a pressure gage. The system was designed so that pressure could be released if it exceeded $0.7 \mathrm{MPa}$. The surrounding alcove had similar instrumentation so tunnel environment changes could be factored into evaluations.

There were two systems to measure rock-wall temperatures. Thermocouples were either heater mounted or bonded to the rock-wall in silicone rubber inserts that fit into pre-cut slots. The heatermounted thermocouples were designed so that the spring action of the insulating sheath would hold the thermocouple against the rock wall. One of the objectives of these experiments was to evaluate the relative merits of the two thermocouple configurations, but this evaluation is unfinished and beyond the intended scope of this paper. Preliminary indications are that the heater-mounted thermocouples appeared to be influenced by direct radiation and sheath conduction so that recorded temperatures were about $20^{\circ} \mathrm{C}$ hlgher than those determined by the rockmounted insert thermocouples. The heater-mounted thermocouples proved to be excellent sensors for evaluating borehole annulus heat transfer effects. For the purpose of this paper all rock-wall data are from the insert thermocouples except in one case (nonwelded, Level 1) where heater-mounted thermocouples were adjusted to the equivalent insext the rmocouple value. Table 1 summarizes the location and type of thermocouples used at each level in the two experiments.

\section{OPERATIONS}

Heater

Table 2 summarizes the pertinent details for heater operations. There were two heating stages for the experiment in welded tuff. After the inttial heating period and a seven-day cooldown, the borehole was flooded, with the heater in its initlal position. The botton $0.3 \mathrm{~m}$ of the hole was saturated for a full seven days, and the fractured tuff up to a height of $1.8 \mathrm{~m}$ was under water for a period of approximately 15 hours. A manually operated steady-state flow system was used to maintain the elevated water level for this shorter period of time. At the end of the flooding period, the free water was removed.

The heater power level chosen for the welded tuff experiment was similar to that used in the TuFf In Situ Water Migration/ Heater Experiment (Johnstone, Hadley 1980). Major aifferences in-mese experiments were orientations of the boreholes and water sampling schemes. In both experinents the heaters had simflar shapes and dimensions. The wattage for the nonwelded experiment was selected so that the maximum tuff temperatures would be well into the zeolite dehydration range ( $\left.>100^{\circ} \mathrm{C}\right)$ and thermal contraction would be expected (Lappin 1980). Heating periods were terminated when trends were apparent and 1 ittie could be gained with additional heat and time.

One change was made after completing the experiment in welded tuff. The heater power reflected variations in the commercial electrical power that was distributed to G-tunnel. Influences of these variations could be seen in many of the thermocouples. The problem was corrected by operating the heater power on an uninterruptible power supply (UPS) for the experiment in nonwelded tuff. 
Table 1. Thermocouple Detai is

\begin{tabular}{|c|c|c|c|c|c|}
\hline $\begin{array}{l}\text { Location } \\
\text { Function }\end{array}$ & Level & $\begin{array}{l}\quad \text { Welded } \\
\text { Thermo* } \\
\text { Type }\end{array}$ & Height** & $\begin{array}{l}\text { Nonwelde } \\
\text { Thermo } \\
\text { Type }\end{array}$ & Height \\
\hline Heater & 1 & $\mathrm{H}, \mathrm{H}, \mathrm{H}$. & $4.1 \mathrm{~cm}$ & $\mathrm{H}, \mathrm{H}, \mathrm{H}$. & $4.1 \mathrm{~cm}$ \\
\hline \multirow[t]{4}{*}{ Surface } & $\begin{array}{l}2 \\
3\end{array}$ & $\begin{array}{l}\mathrm{H}, \mathrm{H}, \mathrm{H} . \\
\mathrm{H}, \mathrm{H}, \mathrm{H} .\end{array}$ & $\begin{array}{l}41.0 \mathrm{~cm} \\
78.7 \mathrm{~cm}\end{array}$ & $\begin{array}{l}\mathrm{H}, \mathrm{H}, \mathrm{H} \\
\mathrm{H}, \mathrm{H}, \mathrm{H} .\end{array}$ & $\begin{array}{l}41.0 \mathrm{~cm} \\
78.7 \mathrm{~cm}\end{array}$ \\
\hline & 4 & $\mathrm{H}, \mathrm{H}, \mathrm{H}$. & $116 \mathrm{~cm}$ & $\mathrm{H}, \mathrm{H}, \mathrm{H}$. & $116 \mathrm{~cm}$ \\
\hline & 5 & $\mathrm{H}, \mathrm{H}, \mathrm{H}$. & 139 & $\mathrm{H}, \mathrm{H}, \mathrm{H}$. & 139 \\
\hline & 6 & $\mathrm{H}, \mathrm{H}, \mathrm{H}$. & 168 & $\mathrm{H}, \mathrm{H}, \mathrm{H}$. & 168 \\
\hline \multirow[t]{7}{*}{ Rock Wall } & 1 & $R, T, T$. & $5 \mathrm{~cm}$ & $\mathrm{~T}, \mathrm{~T}, \mathrm{~T}$. & $5 \mathrm{~cm}$ \\
\hline & 2 & $R, T, T$. & $59.7 \mathrm{~cm}$ & $R, R, T$. & $63.5 \mathrm{~cm}$ \\
\hline & 3 & $\mathrm{R}, \mathrm{T}, \mathrm{T}$. & $95.2 \mathrm{~cm}$ & $R, R, T$ & $117 \mathrm{~cm}$ \\
\hline & 4 & $\mathrm{R}, \mathrm{T}, \mathrm{T}$ & $139 \mathrm{~cm}$ & $\mathrm{R}, \mathrm{T}, \mathrm{T}, \mathrm{T}$. & 140 \\
\hline & 5 & $R, T, T$. & 176 & $R, T, T, T$. & 108 \\
\hline & 6 & $R, R, R$. & 208 & $R, R, R$ & 203 \\
\hline & 7 & $R, R, R$. & 254 & -- & -- \\
\hline
\end{tabular}

$\bar{*} \overline{\mathrm{H}}$ - Heater Surface, R-Rock-Wall Insert, $\mathrm{T}$ - Heater Nounted Tip-Out

**Height measured from bottom of hole

Table 2. Heater Operation

\begin{tabular}{|c|c|c|c|c|c|}
\hline Experiment & $\begin{array}{l}\text { Time } \\
\text { Start }\end{array}$ & & $\begin{array}{l}\text { Time } \\
\text { Stop }\end{array}$ & Duration & Wattage \\
\hline $\begin{array}{l}\text { Welded- } \\
\text { Initial }\end{array}$ & $\begin{array}{l}\text { Apr } 12, \\
1600\end{array}$ & '82- & $\operatorname{May}_{0900} 4, \quad 82-$ & 21.67 days & 800 \\
\hline $\begin{array}{l}\text { Welded- } \\
\text { Reheat }\end{array}$ & $\begin{array}{l}\text { May } 19, \\
0900\end{array}$ & '82- & $\begin{array}{l}\text { May } 26, ' \delta 2- \\
1230\end{array}$ & 7.19 days & 800 \\
\hline Nonwelded & $\begin{array}{l}\text { Aug } 31 \text {, } \\
1100\end{array}$ & '82- & $\begin{array}{l}0 \operatorname{let} 5, \quad 82- \\
1100\end{array}$ & 35.00 days & 500 \\
\hline
\end{tabular}


Data System

The data acquisition system was designed around an HP 9845 desk top computer located underground. Data on all channels (80) were collected in periodic scans. The sinortest scan interval of five minutes was used immediately before and after all changes in the heater power levels. As the thermal phenomena stabilized, the scan interval was lengthened to a maximum of 30 minutes. Most data were taken at the longer intervals.

\section{Thermal Results}

The thermal results for both experiments are summarized in Figures 2 and 3 . Heater $i$ nd rock-wall temperatures are displayed as the ratio of temperature change to power level so that common ordinates can be used. The temperature changes are normalized with the constant power level rather than with thermal diffusivity or conductivity because of the temperature dependence of the latter. To a llow for curve ir.itialization an initial teinperature of $18^{\circ} \mathrm{C}$ was subtracted from a 11 measured temperatures, except for the reheating data, before dividing by the power level. A temperature of $24^{\circ} \mathrm{C}$ was subtracted from the reheat data to factor uut the residual temperature that existed when the heater power was turned on.

\section{Heater Midplane}

Maximum rock-wall temperatures were recorded near the heater midplane (Level 2 in Table 1). Maximum heater surface remperatures were measured above this midplane at Level 3. Results are displayed in Figure 2 .

Let me present first the welded tuff heater and rock-wall thermal results. Irregularities in the curves at the later times are due to irregularities in the heater power. The peak at $t=3 \times 10^{4}$ minutes is due to a surge caused by the temporary sulustitution of power from the

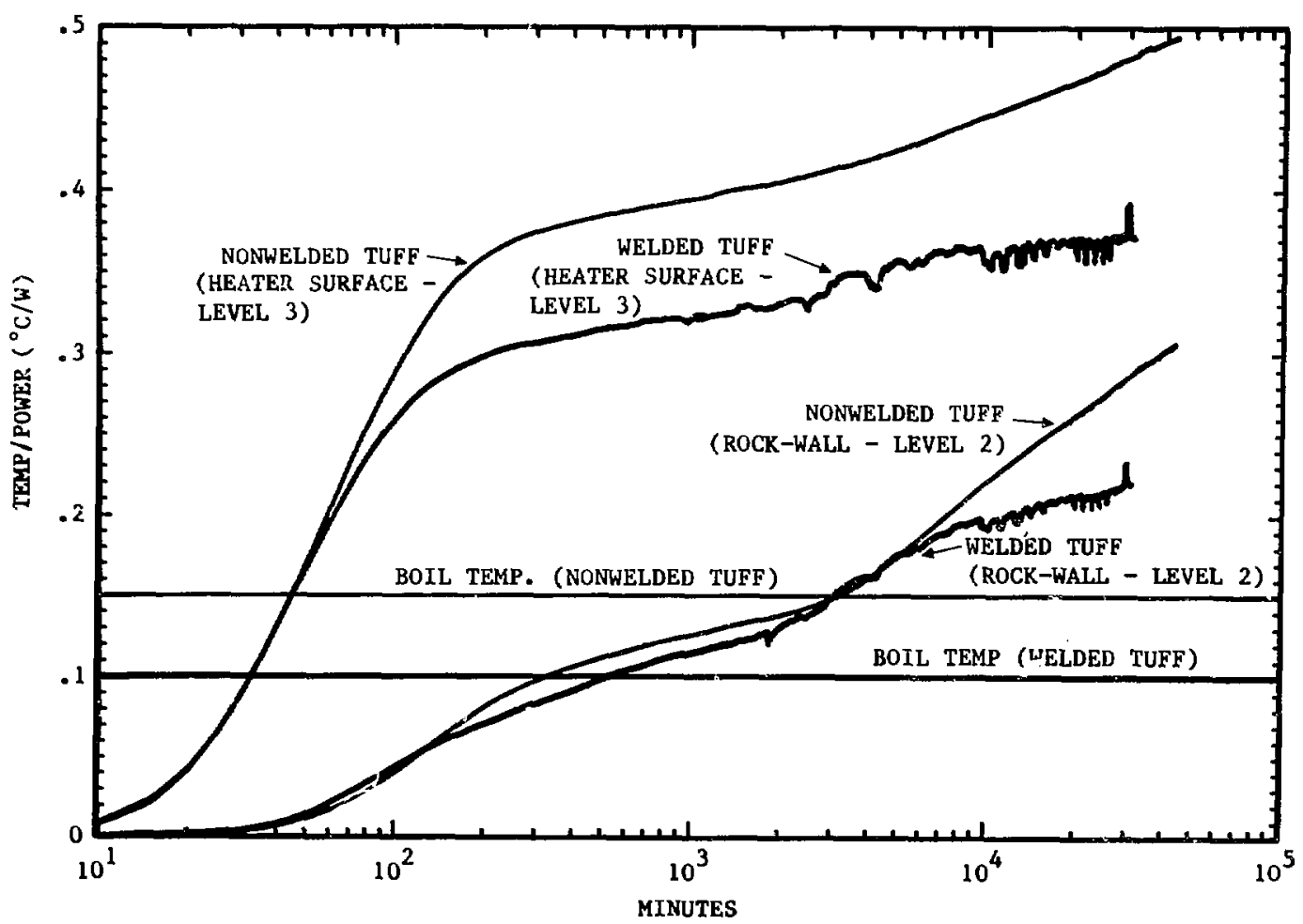

Figure 2. Maximum Rock-Wall and Heater-Surface Temperature Results 


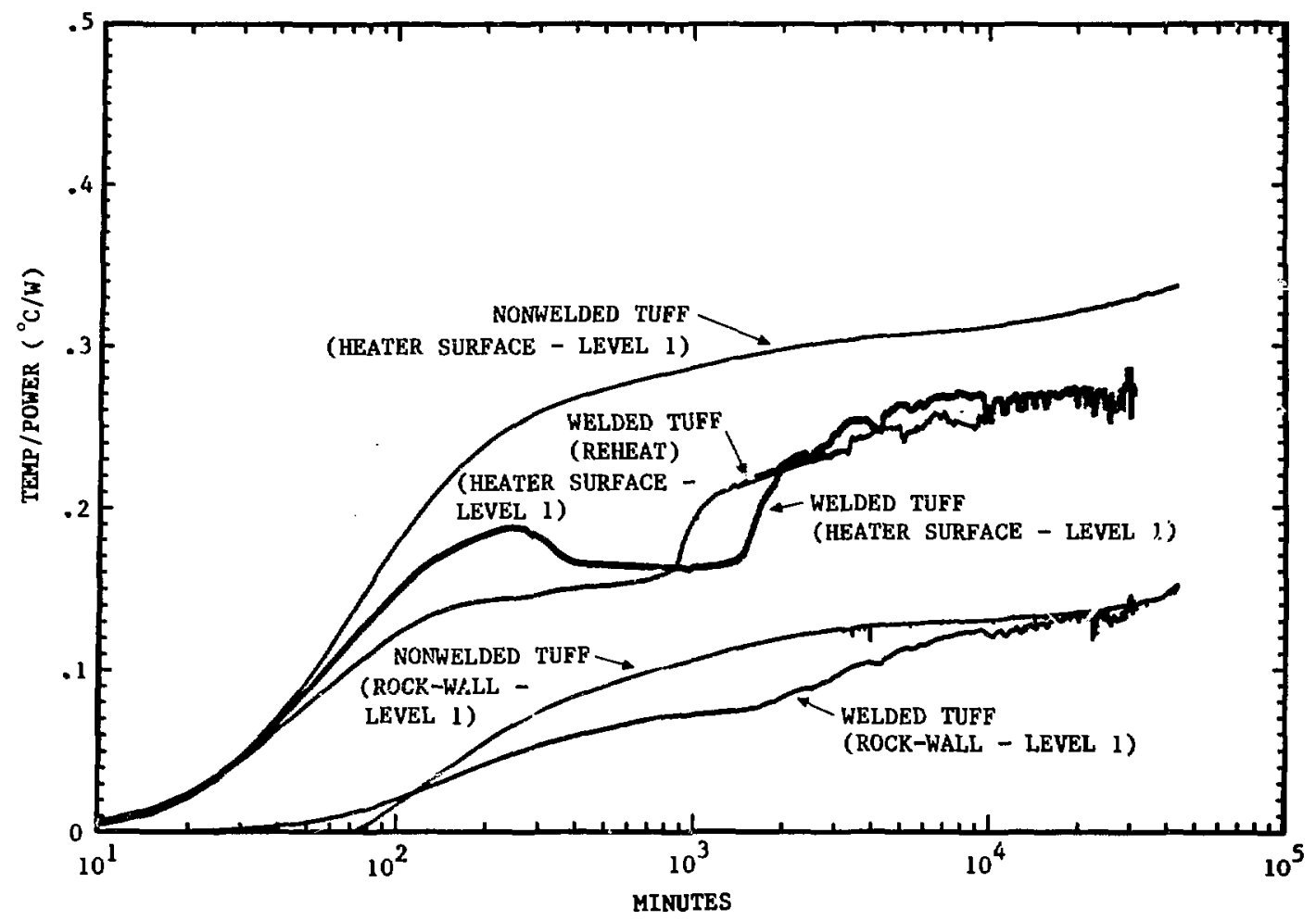

Figure 3. Level 1 Rock-Wall and Heater Surface Temperature Results

autostart diesel that was used for emergency power. The intersection of the horizontal line marked "boil temp. (welded)" and the normalized data curve for the rock wall represents the time when the rock-wall temperature exceeded the local boiling temperature of water (94-18: 800). At about $t=1.8 \times 10^{3} \mathrm{~min}$ the slope for the rock-wall data increased slightly, suggesting a decrease in thermal conductivity. The latent heat of vaporization is a factor that would tend to fiatten the curves, but its presence is not observed. The temperature difference between the heater surface and rock wall decreased after the vaporization started, a further indication of the decreasing heat transfer properties of the dewatered tuff.

The thermal results for the experiment in nonwelded tuff are more uniform because of the regulated power supply. The curves show that the changes in slopes after vaporization $(94-18 \div 500)$ are much more profound, due to the higher porosity and water content in the nonwelded tuffs (relative properties are provided in the thertnal modeling section). The signiflcance of these changes in slopes is that heater and borehole temperatures rise significantly as a result of decreased rock thermal conductivity as pore water is vaporized.

haximum temperatures reached in both experiments were:

Experiment Max Rock Temp

Max. Heat

Welded Tuff $\quad 196^{\circ} \mathrm{C} \quad 317^{\circ} \mathrm{C}$

Nonwelded Tuff $173^{\circ} \mathrm{C} \quad 265^{\circ} \mathrm{C}$

The data in Figure 2 indicate that the nonwelded tuff was still increasing in 
temperature at a significant rate after 35 days of operation, whereas the welded tuff was nearing a maximum temperature after only 21 days of heating.

Post-experiment observations indicated that both heater holes appeared to be structurally stable and intact after the heater was removed. There was no evidence of borehole sloughing due to heating.

\section{Lower Heater}

Figure 3 shows the heater surface and rock-wall temperature changes for Level 1 (Table 1). Levil $\perp$ reheat data for the heater are also shown because this is the only level where there were perceptible differences.

The most significant phenomenological events are reflected in the curves for the heater surface for the welded tuff experiunent. There was a dip in the temperature of the neater surface at times between 240 and $2000 \mathrm{~min}$ for the initial welded tuff heater experiment. The reheat experiment showed similar results with the exception that there was not the initial hump at $t=$ $240 \mathrm{~min}$ and that the increase in slope started some $500 \mathrm{~min}$ earlier. The figure shows that the welded tufi rock-wall temperature was below the nomimal boiling temperature (temp/power $=0.095$ ) during this period. The dip in the heater temperatures is attributed to hydrothermal phenomena. It is hypothesized that pore water in the nearly saturated tuff migrated to the emplacement hole and collected there. This particular borehole had an irregular bottom after drilling, and approximately $1000 \mathrm{cc}$ of crushed tutf were placed in the hole to provide a level surface. This crushed tuff would have a storage capacity estimated to be less than $0.2 \mathrm{l}$. The possibility exists that liquid water collected in this void space and possibly around the bottom of the heater and increased the thermal conductivity in this region for the period when the rock wall temperatures were below boiling. Later discussions of hydrothermal phenomena provide additional data to support this hypothesis.

The reheat experiment data support the general trends, and the two differences can be explained. The absence of the hump at $t=240 \mathrm{~min}$ is attributed to the $1 \mathrm{imi-}$ tations in removing the water from the crushed tuff at the bottom of the hole with the heater in place. The hole was vacuumed dry before placing the heater initially, The earlier increase $(t=1 \mathrm{x}$ $10^{3}$ min) in the slope of the eheat curve is perhaps due to the limitations in resaturating the tuff above 0.3 m during the flooding periods. Possibly, the tuff in the initial heater experiment had more pore water available.

\section{Heater Pressure Unit}

Measurements in the heater pressure unit were enlightening. For the welded tuff experiment the HPU temperature increased by only $4^{\circ} \mathrm{C}$ over the entire experiment, indicating minimal convection to tne top of the deeper borebole. For the experiment in nonwelded tuff, the HPU temperature increased by $15^{\circ} \mathrm{C}$ within $4800 \mathrm{~min}$ and reached a plateau. At $t=$ 29,000 min the HPU was wrapped with insulating fiberglass and the HPU temperature increased by another $20^{\circ} \mathrm{C}$. This indicated that the HPJ was dissipating energy that was being carried upward by convestion in the borehole annulus. The annulus was $0.6 \mathrm{~cm}$ wide around the aluminum honeycomb.

The data indicated that there was a strong convective driving force in the nonwelded tuff, whereas it was relatively minor for the welded tuff. The difference was posited as vapor transport into the fractures. This concept is supported with hydrothermal data discussed next.

\section{HYDROTHERMAL RESULTS}

\section{Borehole Water Migration}

Water migration into a heated borehole was much different than the earlier In Situ Heater/Water Migration Experiment in welded tuff (Johnstone, Hadley 1980). In that experiment over $60 \mathrm{l}$ of water was collected in 63 days of operation. The highest flow rate was in the first few days. A major difference in experimental setups was that the water collection sampling location for this earlier experiment was located beneath the heated region and remained cool. For both of the small diameter heater experiments the total amount of collected water was less than $1 f$.

Hydrothermal phenomena were monitored with three different measurement systems. The accumulation of liquid water in the bottom of the borehole was monitored with the water level sensors. The presence of water vapor and the possible formation of refluxing cells in the borehole was monitored with the heater-mounted thermocouples. The evidence of water migration to the HPU was monitored by the environmental monitors located there. 
The water level sensor was nonstandard and merits a description. It was formed by exposing the two leads for a sheathed thermocouple at a destred level along the heater surface. The thermocouple wires were energlzed with an alternating current so that a circuit juld be completed by conduction through the air between the exposed leads. The sensitivity was set so that there would be an increase of 5-7 volts if any water containing ions were to come in contact with the exposed leads.

The only water level sensor that detected water was the one at the bottom of the heater. Figure 4 summarlzes the responses of this water level sensor. The next potentially active sensor was $2.5 \mathrm{~cm}$ higher and no signal was recorded.

The two curves for the welded tuff have interesting similarities and differences. The simflarities are that they have initial dips between 20 and 200 ,nin, then relative increases through the next $400 \mathrm{~min}$ and then decreases to near zero. The significance of the behavior for the region between 240 and $2000 \mathrm{~min}$ is that this is the same tive period talt the Level 1 heater surface temperatures were lower (Figure 3). This apparently coupled phenomenon suggests that the water migrated into the borehole in liquid form. The earlier dip for $t=120$ min is thought to be due to the initial dewatering of the bottom of the hole as the heater surface reached the boiling temperature at about $t=50 \mathrm{~min}$.

The reason the initial voltage was higher for the reheat experiment is that the moisture in the crushed tuff could not be removed with the heater in place. A further possibility is that additional minerals collected during the Initial heat Ing phase and increased the conductivity of the water.

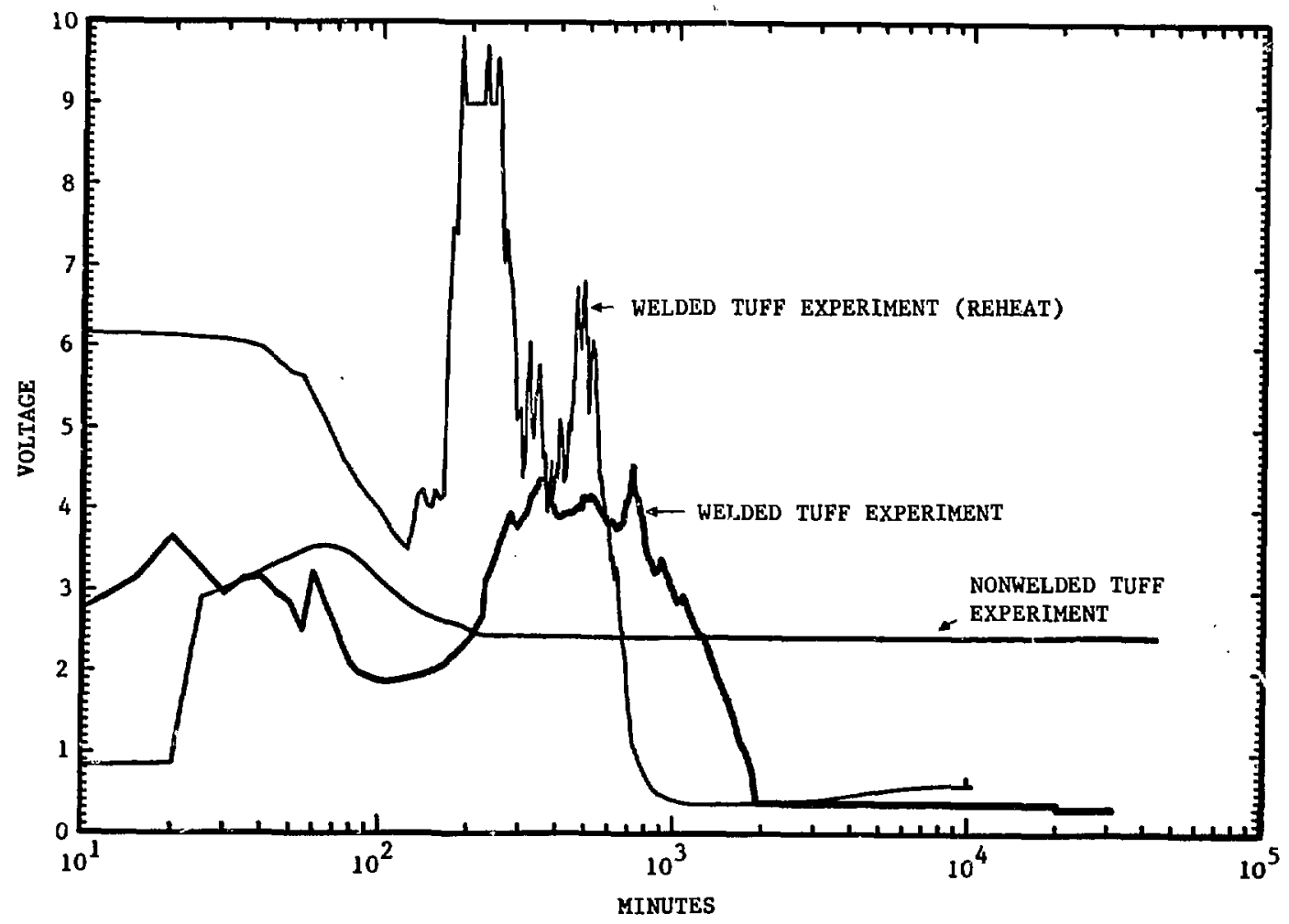

Figure 4. Lowest Water Level Sensor Results 
The curve for the initial experiment in welded tuff shows that the water level sensor was exposed to water for a longer period. This supports the hypothesis that the pore space of the tuff was not fully recharged during the brief flooding period.

The water migration phenomena for the experiment in nonweided tuff were somewhat different. The figure shows that there was some slight increase in voltage for the first $70 \mathrm{~min}$ and then a single decrease and stabilization. There were no apparent influences on the temperatures at the bottom of the heater. Only the water level sensor indicated that there might have been a trace of liquid water. The heater bottom reached a boiling teniperature in about $100 \mathrm{~min}$, and the decreasing inagnitudes of the moisture curve after this time suggest this influence. The fact that the sensor stabilized above $2 \mathrm{~V}$ is attributed to sensor variations because post-experiment analyses indicated that there wouid have been a significant voltage increase if 1 iquid water were present. Vapor appeared to migrate towards the warmer air and then to be transported upward by convection. This vapor-

transporting air cooled in the HPU and the moisture condensed. This was particularly evidenced in the experiment in nonwelded tuff where more than $0.5 \ell$ of water was found in the handling pipe located above the heater. Water was found on the base plate of the HPU for this same experiment. By contrast, only droplets were found in a similar region for the welded tuff experiment. $1 \mathrm{t}$ is conceivable that water vapor was present in the annulus in the welded tuff, and that it was transported into the fractures where it condensed.

\section{HPU Environmental Changes}

Environmental conditions within the HPU and the surrounding alcoves were monitored for temperature, pressure, and relative humidity changes. The most pronounced changes occurred in the relative humidity in the HPU. Saturation was reached withia 12 hours in both experiments. The cemperature increases have already been discussed. Pressure changes were negligible for both the welded and nonwelded tuff experiments.

PRELIMINARY MODEL EVALUATIONS

Mode1 Definition

The preparation of the experiments for the Phase II testing includes an evalu- ation of the state of the current models. While the preparation of a computer code for the analysis of two-phase flow in tuff is underway at Sandia National Laboratorles, an empirical approach has been used to describe the effects of pore water vaporization on the conductive heat transfer process (Eaton et.al., in preparation). The techniques of this empirical approach have been applied to the conditions for the two heater experiments and mode1 - data comparisons are presented here. These comparisons are used as a feedback mechanism fo: ongoing code and material property evaluations.

The design of the experiments allowed use of two-dimensional, axially symmetric, finite element teciniques. The heater surface was modeled as a conductive and radiative surface with a volumetr'c heat generation over the heated volume.

Components within the heater were modeled as equivalent parts of axial symmetry. No attempt was made to compare internal haater model and measured values. The emphasis was on the heater and rock-wall surfaces. The rock-'vall surface was modeled for radiation and conduction.

The thermal conductivity and heat capacity values for welded tuff were specified for the temperature ranges according to the representatlve curves in Figure 5. The figure shows that the thecmal conductivity is changed in two step decreases as the temperature is increased from 70 to $120^{\circ} \mathrm{C}$. The first step represerits the average of the saturated and dry conditions whereas the second represents the dry properties (dewetered). The figure shows that the haat of vaporization is added to the nominal volumetric heat capacities for the tuffs by distributing it over the 70 to $120^{\circ} \mathrm{C}$ range. This procedure allows for a more gradual transition for the vaporization phenomena.

Cores from the boreholes drilled for these experiments were subjected to laboratory analyses (see Table 3 ). These data were used in the material property definitions shown schemarically in Figure 5 . other pertinent model data are included in the table.

\section{Model/Data Comparisons}

Figure 6 is organized so that the heater surface and rock-wall thermal profiles for both experiments can be shown together. Comparisons of the Ist and 21st days of operation illustrate the relative $t$ ime independence of the trends. The major factor evidenced is that the overall heat transfer computer models appear to be adequate for tuffs having vastly different 

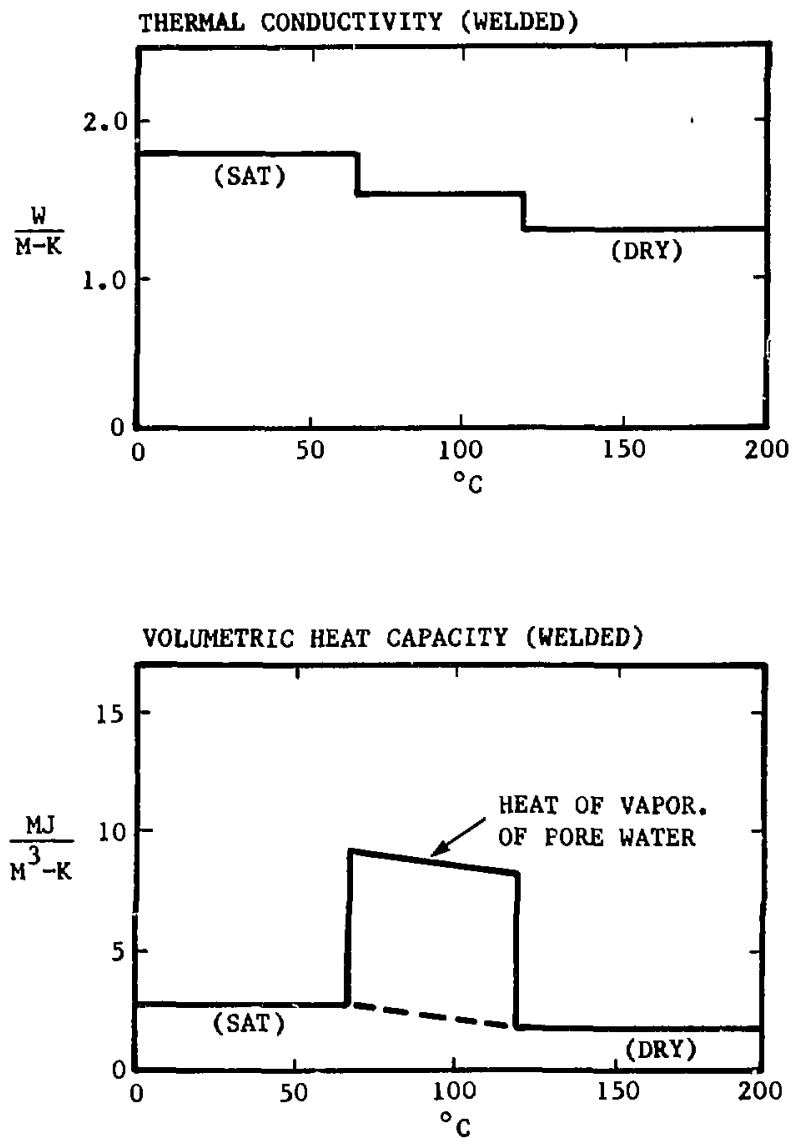

Figure 5. Thermal Model Representation

Table 3. Core and Model Material Properties

\begin{tabular}{|c|c|c|c|}
\hline Property & Units & $\begin{array}{l}\text { Welded } \\
\text { Tuff }\end{array}$ & $\begin{array}{l}\text { Nonvelded } \\
\text { Tuff }\end{array}$ \\
\hline Therma1 Cond. (Sat.) & $\mathrm{W} / \mathrm{m}^{\circ} \mathrm{K}$ & 1.80 & 1.30 \\
\hline Tinermal Cond. (Dry) & $\mathrm{W} / \mathrm{m}$ OK & 1.44 & 0.66 \\
\hline Heat Capacity (Sat.) & $\mathrm{KJ} / \mathrm{m}^{3} \mathrm{o}_{\mathrm{K}}$ & 2478 & 2964 \\
\hline Heat Capacity (Dry) & $\mathrm{KJ} / \mathrm{m}^{30} \mathrm{~K}$ & 1858 & 1105 \\
\hline $\begin{array}{l}\text { Heat of Vaporization of } \\
\text { Pore Water }\left(70<\mathrm{T}<120^{\circ} \mathrm{C}\right)\end{array}$ & $\mathrm{KJ} / \mathrm{m}^{30} \mathrm{~K}$ & 6550 & 19,650 \\
\hline Density (dry bulk) & $\mathrm{KJ} / \mathrm{m}^{3}$ & 2220 & 1320 \\
\hline Porosity & & 0.15 & 0.45 \\
\hline Saturation (measured) & & 0.85 & 0.90 \\
\hline Saturation (model value) & & 1.00 & 1.00 \\
\hline $\begin{array}{l}\text { Emissivity - Heater Surf. } \\
\text { (assumed) }\end{array}$ & & 0.6 & 0.6 \\
\hline Emissivity - Rock (assumed) & & 0.9 & 0.9 \\
\hline
\end{tabular}



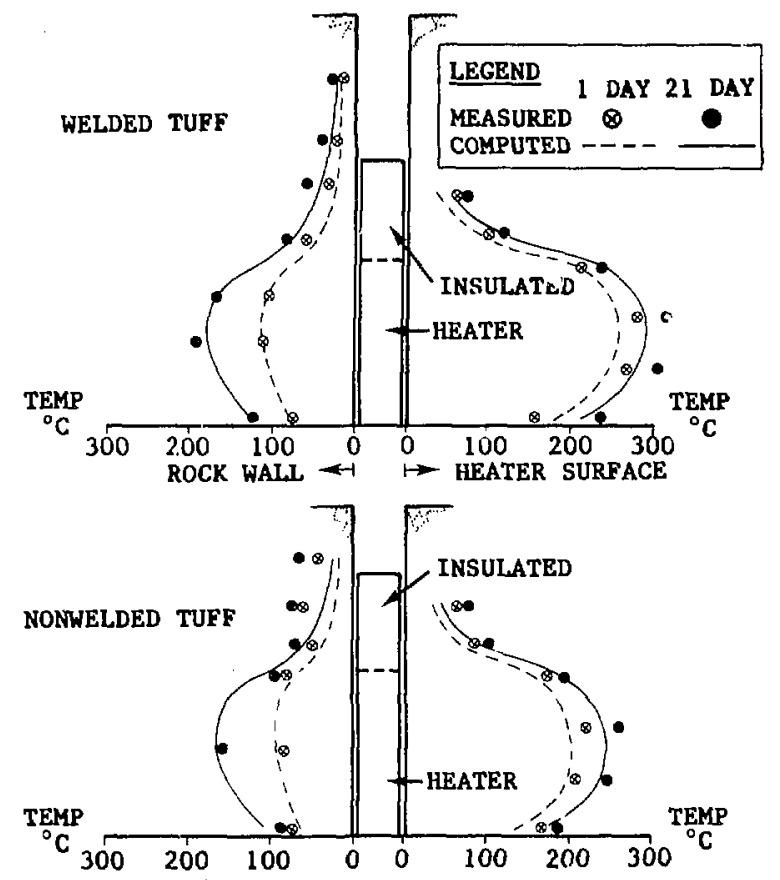

Pigure 6. Measured and Predicted Temperature Distributions on the Heater Surface and Roch-Wall 1 and $2 \perp$ Days After Heater Turn On

porosities and mineralogy.

The figure shows that the measured data for both heater surfaces are generally higher than the computed values. Deviations occur in two places. Differences in the heated region are attributed to assumed values for the heater and rock-wall emissivities, and planned emissivity measurements on these surfaces should reduce these differences. The figure also shows that there are differences above the heated zone. The differences are greater for the experiment in nonwelded tuff. These differences are attributed to convection in the horehole annulus. This phenomenon is even wore pronounced in the rock-wall model comparisons in this same region.

An unexplained measurement trend in the figure is the apparent temperature increase at Level 5 as compared to Level 4 for the nonwelded tuff rock-wall data.
This could be due to two reasons. First, the thermocouple at this level could have become dislodged and moved nearer the heater. Second, a refluxing cell could be influencing the temperatures at this level.

The convection phenomenon is present but less evident for the rock wall of the welded tuff experiment. Data show that convection may be inportant for modeling the very neat field around the borehole, but that thermal impacts on thermomechanical behavior in the surrounding tuffs should be minimal.

As for differences in the rock-wall data/model values, measured maximum temperatures for the nonwelded tuff were approximately $6 \%$ less than the model values, whereas the similar values were approximately $5 \%$ higher for the welded tuff. Apparently, additional convection in the nonwelded tuff experiment caused the lower measured temperatures in the heated regior. 
These plienomenological evaluation experiments in welded and nonwelded tuffs have shown that:

1. The same heat transfer modeling technique can be used for tuffs having porosities of 0.15 and 0.45 , and maximum temperature data/model comparisons were within $6 \%$. Convection should be integrated into near field models if accuracies are to be improved .

2. Only small amounts of liquid water were detected in the bottom of the boreholes. Major water transport mechanisms appear to be the accumulation of vapor in the warmer air around the heater and later deposition as condensate in cooler regions away from the heater.

3. Borehole surfaces did not show structural degradation. While measurements were not taken in the rock outside of the borehole, results show that there is the potential for pore moisture vapor transport into the fractures and this could impact joint motion in the thermomecilanical evaluations.

\section{ACKNOWLEDGEMENTS}

These experiments were performed by a team coordinated within Sandia National Laboratories. The analyses are those of the author, but the experiments could not have been performed without invaluable contributions from the remainder of the team. Willian Barrett prepared and operated the various facets of the data acquisition system. Carl Duimstra prepared the hardware and instrumentation. Both contributed to data evaluations. John Lindman helped field the experiments and monitored the equipment during the heater periods. Steve Winters helped fabricate the water level sensor. Dave Sanders and Jack Suttor of SAI helped prepare the experiment in nonwelded tuff. Fina1ly, John Osnes of RE/SPEC. performed the heat transfer calculations. Roger Eaton and Mark Blanford of SNL are thanked for their thorough reviews.

\section{DISCLAIMER}

This report was prepared as an acoount of work sponsored by an agency of the United States Government. Neither the United States Government nor any agency thereof, nor any of their employees, makes any warranty, express or implied, or assumes any legal liability or responsibility for the accuracy, completeness, or usefulness of any information, apparatus, product, or process disclosed, or represents that its use would not infringe privately owned rights. Reference herein to eny specific commercial product, process, or service by trade name, trademark, manufacturer, or otherwise does not necessarily constitute or imply its endorsemeni, recommenciation, or favoring by the United States Government or any agency thereof. The views and opinions of authors expressed herein do not necessarily state or reflect those of the United States Government or any agency thereof. 